\title{
Assessment of Meteorological Drought in Damoh District, M. P., India
}

\author{
Rajesh Khavse* and R. K. Dwivedi \\ Krishi Vigyan Kendra Damoh, JNKVV, Jabalpur, India \\ *Corresponding author
}

Ke y w o r d s
$\begin{aligned} & \text { Meteorological } \\ & \text { Drought, Rainfall } \\ & \text { and Damoh }\end{aligned}$
Article Info
$\begin{aligned} & \text { Accepted: } \\ & 12 \text { August } 2020 \\ & \text { Available Online: } \\ & \text { 10 September } 2020\end{aligned}$

\begin{abstract}
A B S T R A C T
In rainfed agriculture, rainfall has a crucial role to play for suitable crop planning. One hundred nineteen years (1901-2019) annual rainfall data has been analysed to find out yearly meteorological drought occurrence at Damoh district shows that maximum rain $1874.6 \mathrm{~mm}$ is in1990 and minimum rainfall is $614 \mathrm{~mm}$ in 1993 . Annual average rainfall is $1196 \mathrm{~mm}$. Based on rainfall analysis, it was found that during 119 years no severe and extreme drought year was experienced. However, there was 15 moderate drought $(1913,1918,1941,1965,1966,1987,1988,1989$, 1991, 1992, 1993, 2006, 2007, 2014 and 2017) and 45 mild drought (1901, 1902, 1903, 1904, 1905, 1907, 1908, 1909, 1910, 1911, 1912, 1914, 1920, 1921, 1924, 1927, 1928, 1930, 1950, 1952, 1953, 1954, 1957, 1964, 1968, 1972, 1974, 1975, 1979, 1981, 1984, 1986, 1995, 1996, 1997, 1998, 2000, 2001, 2002, 2004, 2009, 2012, 2015, 2018 and 2019) years. The decreasing trend in damoh district and coefficient of determination $\mathrm{R}^{2}=0.004$ indicating only $0.4 \%$ of the variation in annual rainfall can be explained by the regression model. To reduce the problem of water scarcity in drought years, proper rain water harvesting must be done.
\end{abstract}

\section{Introduction}

Rainfall is the most important natural hydrologic event and is a unique phenomenon varying both in space and time. Rainfall distribution is very uneven and it not only varies considerably from place to place but also fluctuates from year to year. It is one of the most important and governing factor in the planning and operation strategies of any agricultural programme for any given area. Agricultural development largely depends upon the management of natural resources. India receives adequate amount of rainfall annually through the four seasons viz., southwest monsoon (74\%), north-east monsoon (3\%), pre-monsoon (13\%) and post-monsoon (10\%) (Dabral et al., 2009). In rainfed farming, the crop planning and its success depend upon the amount and distribution of rainfall. For planning of agricultural operations weekly data are more useful than monthly, seasonal and annual rainfall. 
According to Indian Meteorological Department (IMD), a meteorological subdivision (part of India) can be considered as affected by drought, if it receives total seasonal rainfall less than $75 \%$ of the normal value. The occurrence of drought on a continuous basis leads to reduced availability of fodder, decline in agricultural production, livestock wealth and badly affect the people inhabiting these areas. Drought produces both direct and indirect impacts. Direct or primary impacts are usually physical / material and include reduced agricultural production, increased fire hazards, deplete water level, higher livestock and wildlife mortality rates, and damage to wildlife and fish habitats. Even though drought affects large areas worldwide and has serious impacts on society, environment and economy; it is still one of the least understood of all the weather phenomena.

As such no general method is available which can be applied for the drought prediction (Salas, 1986). Meteorological drought is the condition when a region receives less than half the amount of normal precipitation (IMD, 1971). In spite of having good potential of rain water, Damoh faces the problem of water scarcity during the maximum part of year (Kumar and Rajput, 2013). Shrivastava et al., (2008) assessed meteorological drought in north Lakhimpur district of Assam and Lala I $\mathrm{P}$ Ray et al., in Barapani of Meghalaya. Kumar and Kumar (1989), Dabral (1996) analysed weekly, monthly, seasonally and yearly rainfall data for drought situation at Pantnagar and Ranchi station respectively. Damoh city is the district place of Madhya Pradesh state is located between $23^{\circ}$ 50'20.59" North and 79 $26^{\prime}$ '27.69" East. The average annual rainfall of Damoh district is $1196.0 \mathrm{~mm}$. Damoh district received maximum rainfall during southwest monsoon period i.e. June to September. About $90.7 \%$ of the annual rainfall received during monsoon season. Only $9.2 \%$ of the annual rainfall takes place between October to May period. Thus, surplus water for ground water recharge is available only during the southwest monsoon period. The normal maximum temperature received during the month of May is $42.0^{\circ} \mathrm{C}$ and minimum during the month of December/January is $9.7^{\circ} \mathrm{C}$. The normal annual means maximum and minimum temperatures of Damoh district is $32.6^{\circ}$ and $18.9^{\circ} \mathrm{C}$ respectively. During the southwest monsoon season the relative humidity generally exceeds $88 \%$ (August month). In the rest of the year it is drier. The driest part of the year is the summer season, when relative humidity is less than $31 \%$. May is the driest month of the year. It is at an average elevation of 595 meters $(1,952 \mathrm{ft})$. The district of Damoh has an area of 7,306 square $\mathrm{km}$ (2,821 sq mi).

In maximum part of the district water scarcity is the major problem during maximum part of year (Khan Seraj, 2009, Kumar A and Rajput PS, 2013). Present study aims to analyses the trend of annual rainfall of vital important in all activities which is the only resources of renewable water resource and analyze the cause of scarcity of water.

\section{Materials and Methods}

In the study to analyze the cause of water scarcity (Map) (Fig. 1), yearly precipitation values of Damoh have been obtained from State Metrological Service for meteorological drought analysis. Record intervals of precipitation values are listed in Table 2. Drought year: the annual rainfall is deficient by $20-60 \%$ of average yearly rainfall and if the deficient is more than $60 \%$ of average yearly rainfall is known as scanty drought year (Dhar et al., 1979). Yearly intensity of drought was also determined using the criteria suggested by IMD (1971) which is based on percentage deviation of rainfall from its long term mean and it is given by (Eq.) 
$\mathrm{Di}=\frac{\mathrm{Pi}-\mu}{\mu} \mathrm{X} 100$

Where,

Di is the percentage deviation from the long term mean,

$\mathrm{Pi}$ is the annual rainfall, $\mathrm{mm}$ and

$\mu$ is the long term mean of annual rainfall, $\mathrm{mm}$

Drought codification based on percentage departure of rainfall from normal is presented in Table 1. The percentage of deviation (Di) is then used to categories the drought. On the basis of percentage depature drought conditions are dividing into five categories as No drought (M0), Mild drought (M1), Moderate drought (M2), Severe drought (M3) and Extreme drought (M4).

\section{Results and Discussion}

Year wise, rainfall, long term mean, percent deviation and drought category is shown in table 2 and fig. 2. Meteorological records of Damoh district shows that maximum rain $1864 \mathrm{~mm}$ is in 1990 and minimum rainfall is $614 \mathrm{~mm}$ in 1993. Rainfall of 119 years has been studied and percentage deviation of rainfall is calculated and categorized as No Drought, Mild Drought, Moderate Drought, Severer Drought and Extreme Drought as respectively M0, M1, M2, M3 and M4. In 119 years, no drought/ normal rain years are 59, mild drought years are 45, moderate 15, severe and extreme is nil (Table 3 and Fig. 3). The decreasing trend in damoh district and coefficient of determination $\mathrm{R}^{2}=0.004$ indicating only $0.4 \%$ of the variation in annual rainfall can be explained by the regression model in fig. 4 .

Fig.1 Location map study area (Damoh District)

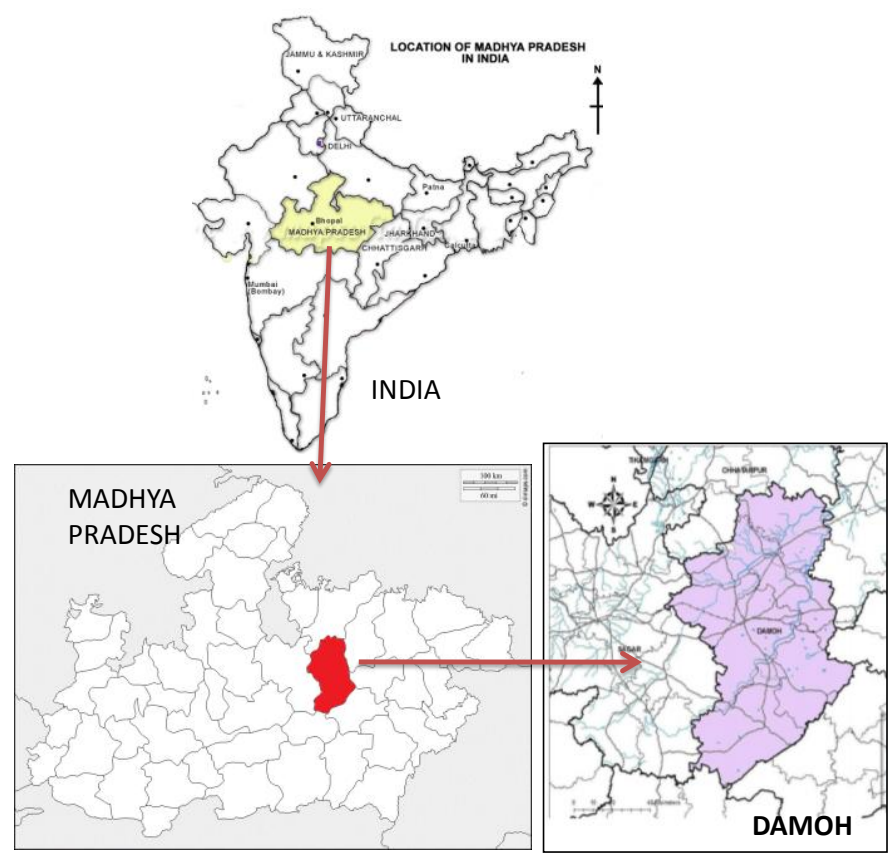


Table.1 Category of drought codification based on percentage deviation of rainfall from normal value (IMD, 1971)

\begin{tabular}{|l|c|c|}
\hline $\begin{array}{c}\text { Percentage departure of } \\
\text { rainfall from normal }\end{array}$ & $\begin{array}{c}\text { Category Intensity } \\
\text { of } \\
\text { Drought }\end{array}$ & Code \\
\hline 0.0 or above & No drought & M0 \\
\hline 0.0 to -25.0 & Mild drought & M1 \\
\hline-25.0 to -50.0 & Moderate drought & M2 \\
\hline-50.0 to -75.0 & Severe drought & M3 \\
\hline-75.0 to less & Extreme drought & M4 \\
\hline
\end{tabular}

Table.2 Yearly intensity of drought for Damoh (Source: Ashwini et al., 2007)

\begin{tabular}{|c|c|c|c|c|c|}
\hline Year & Annual & Normal & Dev. ( \%) & Category & Code \\
\hline 1901 & 1179.7 & 1196.0 & -1.4 & Mild Drought & M1 \\
\hline 1902 & 976.8 & 1196.0 & -18.3 & Mild Drought & M1 \\
\hline 1903 & 1181.6 & 1196.0 & -1.2 & Mild Drought & M1 \\
\hline 1904 & 1093.9 & 1196.0 & -8.5 & Mild Drought & M1 \\
\hline 1905 & 856.4 & 1196.0 & -28.4 & Mild Drought & M1 \\
\hline 1906 & 1212.2 & 1196.0 & 1.4 & No Drought & M0 \\
\hline 1907 & 963.3 & 1196.0 & -19.5 & Mild Drought & M1 \\
\hline 1908 & 1154.8 & 1196.0 & -3.4 & Mild Drought & M1 \\
\hline 1909 & 1093.6 & 1196.0 & -8.6 & Mild Drought & M1 \\
\hline 1910 & 1094.9 & 1196.0 & -8.5 & Mild Drought & M1 \\
\hline 1911 & 1092.1 & 1196.0 & -8.7 & Mild Drought & M1 \\
\hline 1912 & 986.7 & 1196.0 & -17.5 & Mild Drought & M1 \\
\hline 1913 & 824.5 & 1196.0 & -31.1 & Moderate Drought & M2 \\
\hline 1914 & 1025.6 & 1196.0 & -14.2 & Mild Drought & M1 \\
\hline 1915 & 1302.0 & 1196.0 & 8.9 & No Drought & M0 \\
\hline 1916 & 1274.9 & 1196.0 & 6.6 & No Drought & M0 \\
\hline 1917 & 1386.9 & 1196.0 & 16.0 & No Drought & M0 \\
\hline 1918 & 878.9 & 1196.0 & -26.5 & Moderate Drought & M2 \\
\hline 1919 & 1512.7 & 1196.0 & 26.5 & No Drought & M0 \\
\hline 1920 & 965.6 & 1196.0 & -19.3 & Mild Drought & M1 \\
\hline 1921 & 1130.7 & 1196.0 & -5.5 & Mild Drought & M1 \\
\hline 1922 & 1266.1 & 1196.0 & 5.9 & No Drought & M0 \\
\hline 1923 & 1429.4 & 1196.0 & 19.5 & No Drought & M0 \\
\hline 1924 & 1069.7 & 1196.0 & -10.6 & Mild Drought & M1 \\
\hline 1925 & 1325.3 & 1196.0 & 10.8 & No Drought & M0 \\
\hline 1926 & 1337.7 & 1196.0 & 11.8 & No Drought & M0 \\
\hline 1927 & 1189.3 & 1196.0 & -0.6 & Mild Drought & M1 \\
\hline
\end{tabular}




\begin{tabular}{|c|c|c|c|c|c|}
\hline 1928 & 1021.2 & 1196.0 & -14.6 & Mild Drought & M1 \\
\hline 1929 & 1424.4 & 1196.0 & 19.1 & No Drought & MO \\
\hline 1930 & 1094.0 & 1196.0 & -8.5 & Mild Drought & M1 \\
\hline 1931 & 1402.5 & 1196.0 & 17.3 & No Drought & $\mathrm{MC}$ \\
\hline 1932 & 1207.1 & 1196.0 & 0.9 & No Drought & $\mathrm{MC}$ \\
\hline 1933 & 1211.2 & 1196.0 & 1.3 & No Drought & $\mathrm{MC}$ \\
\hline 1934 & 1699.0 & 1196.0 & 42.1 & No Drought & MC \\
\hline 1935 & 1340.5 & 1196.0 & 12.1 & No Drought & MC \\
\hline 1936 & 1245.7 & 1196.0 & 4.2 & No Drought & $\mathrm{MC}$ \\
\hline 1937 & 1275.0 & 1196.0 & 6.6 & No Drought & $\mathrm{MC}$ \\
\hline 1938 & 1371.0 & 1196.0 & 14.6 & No Drought & MC \\
\hline 1939 & 1237.9 & 1196.0 & 3.5 & No Drought & Mo \\
\hline 1940 & 1274.6 & 1196.0 & 6.6 & No Drought & $\mathrm{MC}$ \\
\hline 1941 & 766.1 & 1196.0 & -35.9 & Moderate Drought & $\mathrm{M} 2$ \\
\hline 1942 & 1377.3 & 1196.0 & 15.2 & No Drought & MC \\
\hline 1943 & 1263.6 & 1196.0 & 5.6 & No Drought & MC \\
\hline 1944 & 1684.2 & 1196.0 & 40.8 & No Drought & $\mathrm{MC}$ \\
\hline 1945 & 1369.7 & 1196.0 & 14.5 & No Drought & MC \\
\hline 1946 & 1255.4 & 1196.0 & 5.0 & No Drought & $\mathrm{MC}$ \\
\hline 1947 & 1668.3 & 1196.0 & 39.5 & No Drought & MC \\
\hline 1948 & 1541.4 & 1196.0 & 28.9 & No Drought & MC \\
\hline 1949 & 1387.8 & 1196.0 & 16.0 & No Drought & $\mathrm{MC}$ \\
\hline 1950 & 1065.6 & 1196.0 & -10.9 & Mild Drought & M1 \\
\hline 1951 & 1224.0 & 1196.0 & 2.3 & No Drought & $\mathrm{MC}$ \\
\hline 1952 & 1088.5 & 1196.0 & -9.0 & Mild Drought & M1 \\
\hline 1953 & 1065.5 & 1196.0 & -10.9 & Mild Drought & M1 \\
\hline 1954 & 1160.1 & 1196.0 & -3.0 & Mild Drought & M1 \\
\hline 1955 & 1582.9 & 1196.0 & 32.4 & No Drought & MC \\
\hline 1956 & 1693.2 & 1196.0 & 41.6 & No Drought & MC \\
\hline 1957 & 1041.2 & 1196.0 & -12.9 & Mild Drought & M1 \\
\hline 1958 & 1257.7 & 1196.0 & 5.2 & No Drought & MC \\
\hline 1959 & 1360.8 & 1196.0 & 13.8 & No Drought & MC \\
\hline 1960 & 1465.8 & 1196.0 & 22.6 & No Drought & MC \\
\hline 1961 & 1550.3 & 1196.0 & 29.6 & No Drought & $\mathrm{MC}$ \\
\hline 1962 & 1515.8 & 1196.0 & 26.7 & No Drought & $\mathrm{MC}$ \\
\hline 1963 & 1327.2 & 1196.0 & 11.0 & No Drought & $\mathrm{MC}$ \\
\hline 1964 & 1092.3 & 1196.0 & -8.7 & Mild Drought & M1 \\
\hline 1965 & 792.0 & 1196.0 & -33.8 & Moderate Drought & $\mathrm{M} 2$ \\
\hline 1966 & 861.9 & 1196.0 & -27.9 & Moderate Drought & $\mathrm{M} 2$ \\
\hline 1967 & 1297.2 & 1196.0 & 8.5 & No Drought & $\mathrm{MO}$ \\
\hline 1968 & 980.8 & 1196.0 & -18.0 & Mild Drought & M1 \\
\hline
\end{tabular}




\begin{tabular}{|c|c|c|c|c|c|}
\hline 1969 & 1324.5 & 1196.0 & 10.7 & No Drought & M0 \\
\hline 1970 & 1359.4 & 1196.0 & 13.7 & No Drought & M0 \\
\hline 1971 & 1403.1 & 1196.0 & 17.3 & No Drought & M0 \\
\hline 1972 & 1005.0 & 1196.0 & -16.0 & Mild Drought & M1 \\
\hline 1973 & 1513.6 & 1196.0 & 26.6 & No Drought & M0 \\
\hline 1974 & 1080.7 & 1196.0 & -9.6 & Mild Drought & M1 \\
\hline 1975 & 1179.5 & 1196.0 & -1.4 & Mild Drought & M1 \\
\hline 1976 & 1196.8 & 1196.0 & 0.1 & No Drought & M0 \\
\hline 1977 & 1377.8 & 1196.0 & 15.2 & No Drought & M0 \\
\hline 1978 & 1458.5 & 1196.0 & 22.0 & No Drought & M0 \\
\hline 1979 & 956.9 & 1196.0 & -20.0 & Mild Drought & M1 \\
\hline 1980 & 1286.7 & 1196.0 & 7.6 & No Drought & M0 \\
\hline 1981 & 986.9 & 1196.0 & -17.5 & Mild Drought & M1 \\
\hline 1982 & 1530.7 & 1196.0 & 28.0 & No Drought & M0 \\
\hline 1983 & 1437.8 & 1196.0 & 20.2 & No Drought & M0 \\
\hline 1984 & 915.6 & 1196.0 & -23.4 & Mild Drought & M1 \\
\hline 1985 & 1319.6 & 1196.0 & 10.3 & No Drought & M0 \\
\hline 1986 & 967.7 & 1196.0 & -19.1 & Mild Drought & M1 \\
\hline 1987 & 889.5 & 1196.0 & -25.6 & Moderate Drought & M2 \\
\hline 1988 & 885.5 & 1196.0 & -26.0 & Moderate Drought & M2 \\
\hline 1989 & 855.0 & 1196.0 & -28.5 & Moderate Drought & $\mathrm{M} 2$ \\
\hline 1990 & 1847.6 & 1196.0 & 54.5 & No Drought & M0 \\
\hline 1991 & 752.2 & 1196.0 & -37.1 & Moderate Drought & M2 \\
\hline 1992 & 720.8 & 1196.0 & -39.7 & Moderate Drought & M2 \\
\hline 1993 & 614.6 & 1196.0 & -48.6 & Moderate Drought & M2 \\
\hline 1994 & 1599.0 & 1196.0 & 33.7 & No Drought & M0 \\
\hline 1995 & 1053.8 & 1196.0 & -11.9 & Mild Drought & M1 \\
\hline 1996 & 1063.5 & 1196.0 & -11.1 & Mild Drought & M1 \\
\hline 1997 & 1026.6 & 1196.0 & -14.2 & Mild Drought & M1 \\
\hline 1998 & 1182.8 & 1196.0 & -1.1 & Mild Drought & M1 \\
\hline 1999 & 1282.4 & 1196.0 & 7.2 & No Drought & M0 \\
\hline 2000 & 1002.5 & 1196.0 & -16.2 & Mild Drought & M1 \\
\hline 2001 & 1031.9 & 1196.0 & -13.7 & Mild Drought & M1 \\
\hline 2002 & 903.5 & 1196.0 & -24.5 & Mild Drought & M1 \\
\hline 2003 & 1593.6 & 1196.0 & 33.2 & No Drought & M0 \\
\hline 2004 & 1048.7 & 1196.0 & -12.3 & Mild Drought & M1 \\
\hline 2005 & 1666.8 & 1196.0 & 39.4 & No Drought & M0 \\
\hline 2006 & 806.0 & 1196.0 & -32.6 & Moderate Drought & M2 \\
\hline 2007 & 888.9 & 1196.0 & -25.7 & Moderate Drought & M2 \\
\hline 2008 & 1259.4 & 1196.0 & 5.3 & No Drought & M0 \\
\hline 2009 & 927.3 & 1196.0 & -22.5 & Mild Drought & M1 \\
\hline
\end{tabular}




\begin{tabular}{|c|c|c|c|l|l|}
\hline $\mathbf{2 0 1 0}$ & 1254.8 & 1196.0 & 4.9 & No Drought & M0 \\
\hline $\mathbf{2 0 1 1}$ & 1346.4 & 1196.0 & 12.6 & No Drought & M0 \\
\hline $\mathbf{2 0 1 2}$ & 1110.9 & 1196.0 & -7.1 & Mild Drought & M1 \\
\hline $\mathbf{2 0 1 3}$ & 1721.9 & 1196.0 & 44.0 & No Drought & M0 \\
\hline $\mathbf{2 0 1 4}$ & 850.8 & 1196.0 & -28.9 & Moderate Drought & M2 \\
\hline $\mathbf{2 0 1 5}$ & 914.6 & 1196.0 & -23.5 & Mild Drought & M1 \\
\hline $\mathbf{2 0 1 6}$ & 1707.3 & 1196.0 & 42.8 & No Drought & M0 \\
\hline $\mathbf{2 0 1 7}$ & 757.5 & 1196.0 & -36.7 & Moderate Drought & M2 \\
\hline $\mathbf{2 0 1 8}$ & 949.8 & 1196.0 & -20.6 & Mild Drought & M1 \\
\hline $\mathbf{2 0 1 9}$ & 1160.9 & 1196.0 & -2.9 & Mild Drought & M1 \\
\hline
\end{tabular}

Fig.2 Deviation Percentage of rainfall from normal for Damoh, M. P.

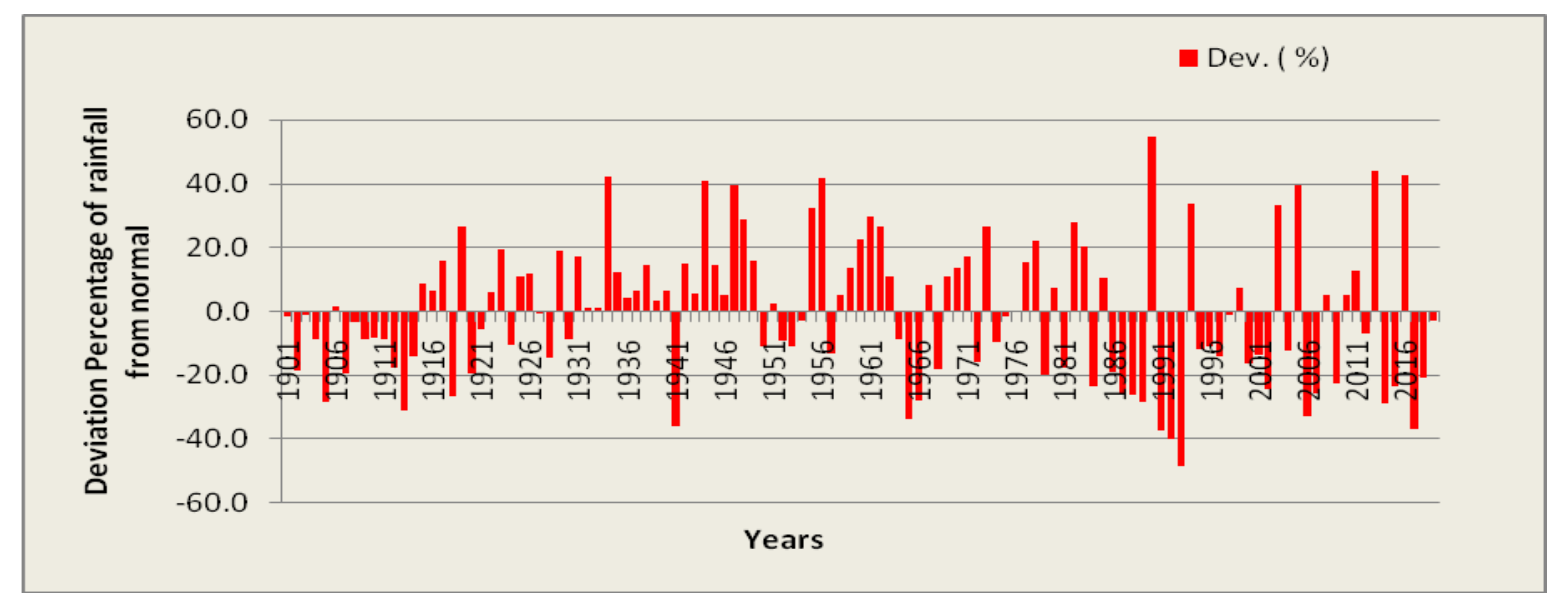

Fig.3 Drought frequencies for Damoh, M. P.

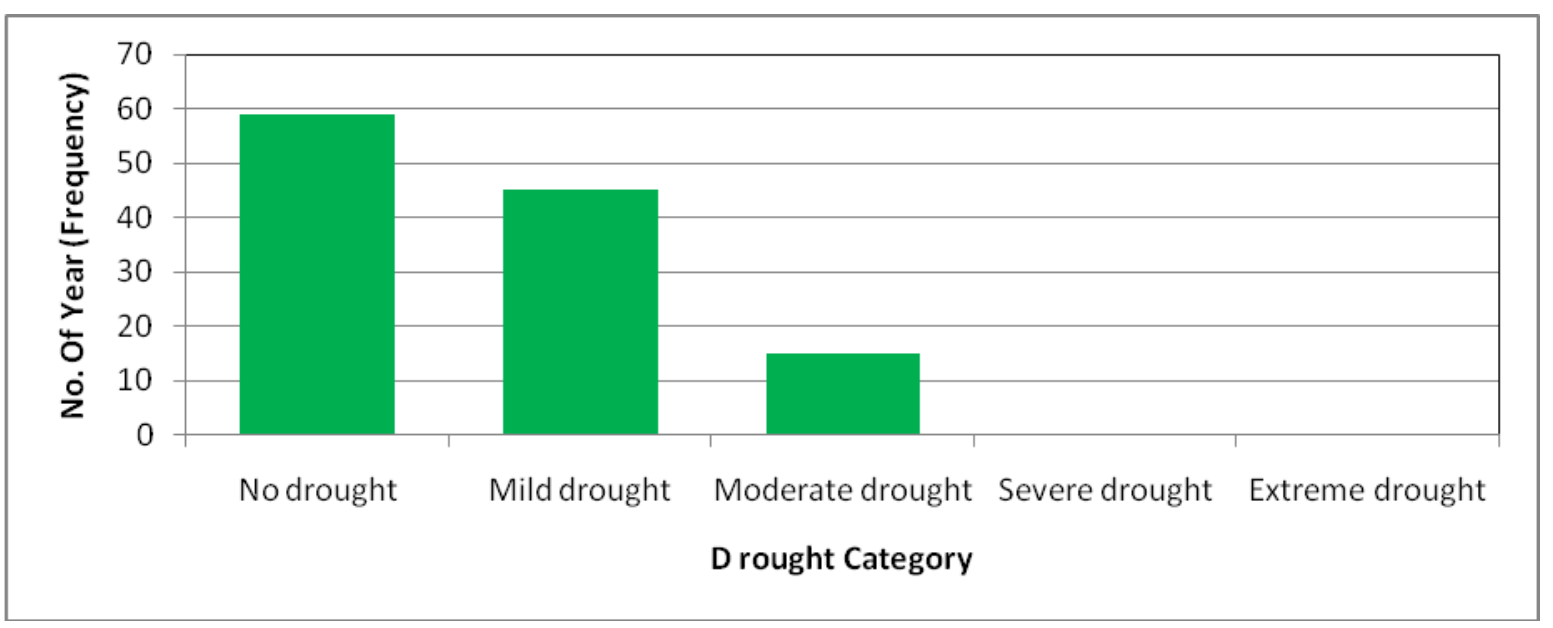


Fig.4 Annual rainfall trends for Damoh, M. P.

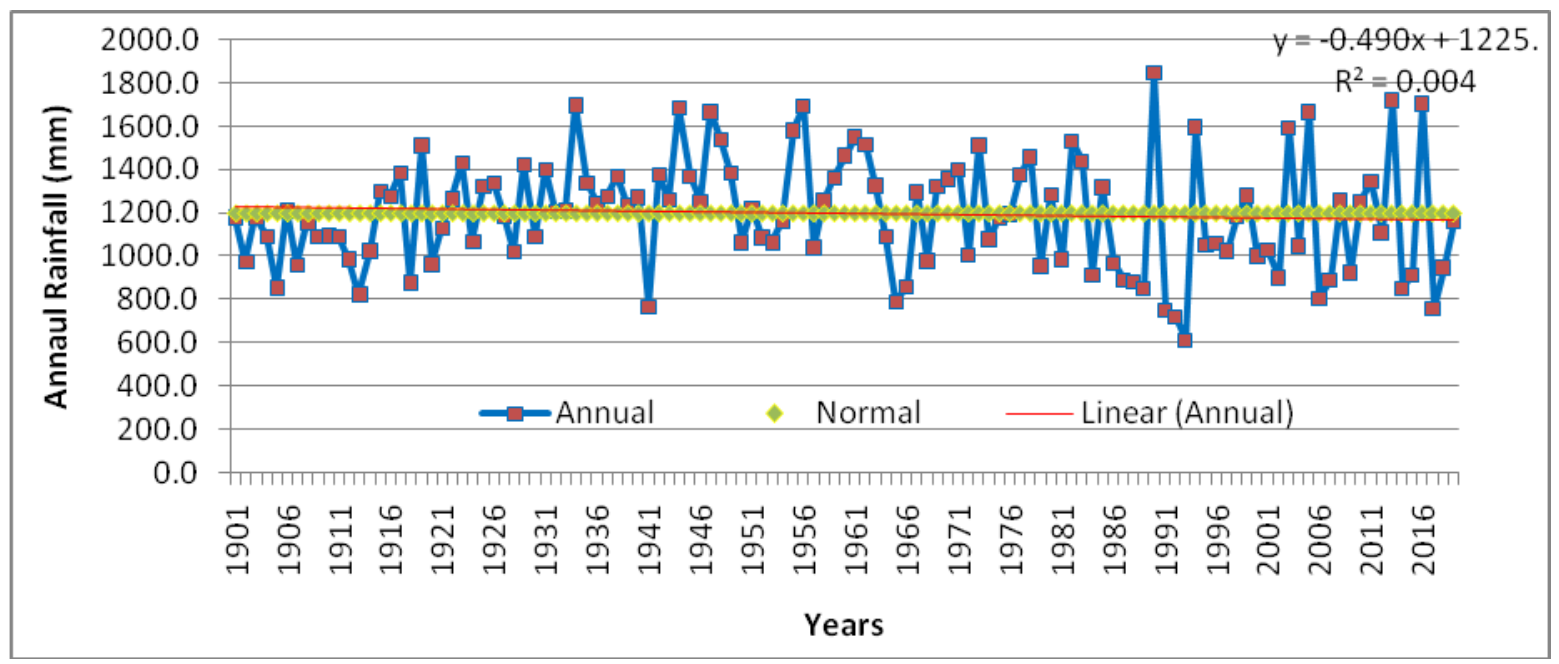

Table. 3 Drought codification based on percentage deviation of rainfall

\begin{tabular}{|c|c|c|c|}
\hline $\begin{array}{l}\text { Category Intensity of } \\
\text { Drought }\end{array}$ & Code & $\begin{array}{l}\text { No of years } \\
(1901-2019)\end{array}$ & $\%$ \\
\hline No drought & M0 & 59 & 50 \\
\hline Mild drought & M1 & 45 & 38 \\
\hline Moderate drought & M2 & 15 & 13 \\
\hline Severe drought & M3 & Nil & Nil \\
\hline Extreme drought & M4 & Nil & Nil \\
\hline
\end{tabular}

Obtained data clearly shows that out of 119 years, number of drought years of different drought intensity is shown in Table 3 and represented in Figure 3. No drought (M0) years which are above the normal average rainfall are $50 \%$. No of years of different intensities of drought are M1 38\%, M2 $13 \%$, M3 and M4 Nil. Within 10 years (every decade) 3 to 4 years face good rain (no drought) \& 4 to 5 years are faces normal / near normal rain (Mild drought) and 1 to 2 year face Severe to extreme drought (Table $3)$.

Conclusion of the study is as follows:

In Damoh district annual rainfall equally deviates $\pm 25 \%$ from normal average yearly rainfall. The yearly rainfall is good but scarcity of water during maximum part of the year and flood situation during monsoon needs proper management of water resources

\section{References}

Ashwini A. Ranade, Nityanand Singh, H.N. Singh and N.A. Sontakke (2007) "Characteristics of Hydrological Wet Season over Different River Basins of India", Indian Institute of Tropical Meteorology Pune.

Berkat, O. and M. Tazi, (2006) "Country Pasture/Forage Resource Profiles MOROCCO".

Dabral P. P. (1996) "Meteorology drought analysis on rainfall data" Ind. J. Soil Cons., 24 (1) 37- 40.

Dhar D. N., Rakheha P. R. and Kulkarni A. 
K. (1979) "Rainfall Study of Serves Drought Years of India", Drought, Vol. I, p. 314, New Delhi.

India Meteorological Department (IMD) (1971) "Climate Diagnostic Bulletin" of India- June, July, August 1971; Rep. No 88, 89 and 90, National Climate Center, IMD, Pune.

Khan Seraj (2009), District Ground Water Information Booklet of Damoh District Madhya Pradesh

Kumar Ajay and Rajput Pushpendra Singh (2013) "Water harvesting potential of Damoh river basin of Damoh M.P.", Bioved, 24(1): 1-7

Kumar Ajay and Rajput Pushpendra Singh (2013) "Water harvesting potential of Damoh river basin of Damoh M.P.", Bioved, 24(1): 1-7

Kumar D. and Kumar S. (1989) "Drought analysis based on rainfall data", Ind. J. Soil Cons., 17 (1) 50- 60.
Lala I. P. Ray, P. K. Bora, V. Ram, A. K. Singh, R. Singh and S. M. Feroze (2012) "Meteorological Drought Assessment in Barapani, Meghalaya", J of Ind. Water Res. Soc, 32 (1), 56- 61.

Raju N. Janardhana, (2007), Hydro geochemical parameters for assessment of groundwater quality in the upper Gunjanaeru river watershed, Cuddapah district, Andhra Pradesh, South India. Environmental Geology 52, 1067- 1074

Salas J. D. (1986) "State of the art of statistical technique for describing drought characteristic WARRDCC, International seminar on Drought Analysis.

Shrivastava S. K., Rai R. K., Pandey A. (2008) "Assessment of meteorological in north Lakhimpur district of Assam", J of Ind. Water Res. Soc., 28 (2) 2631.

\section{How to cite this article:}

Rajesh Khavse and Dwivedi, R. K. 2020. Assessment of Meteorological Drought in Damoh District, M. P., India. Int.J.Curr.Microbiol.App.Sci. 9(09): 1353-1361.

doi: https://doi.org/10.20546/ijcmas.2020.909.165 